\title{
THE PRINCIPLES OF GOOD CORPORATE GOVERNANCE AND LAW ENFORCEMENT
}

\author{
By: Imam Mustofa*
}

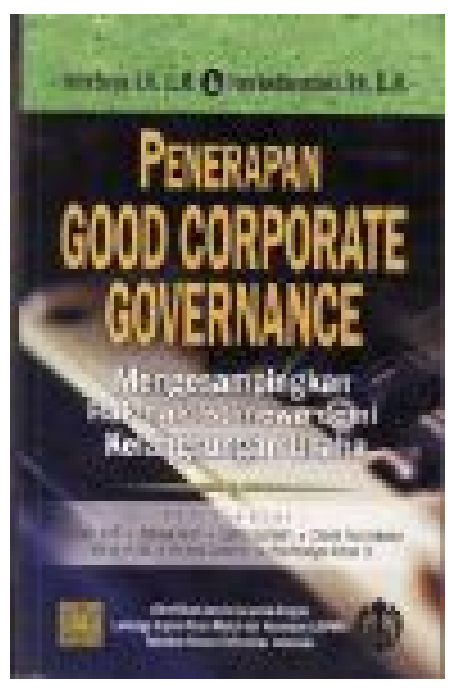

Title : : Penerapan Good Corporate Governance (Mengesampingkan Hak-hak Istimewa Demi Kelangsungan Usaha)

Writer : Indra Surya \& Ivan Yustiavandana

Publication : 2006

Publisher : Kencana

Pages $\quad:$ xii +243 pages

This book is an important guide for corporate stakeholders who implore to get security for their short term as well as long term interest. The writer describes principles of the implementation of good corporate governance, including governance ethics. This book not only provides the explanation of ethics and moral principles, but also includes relevant legal aspects. In addition, it delineates law enforcement as an important part of the implementation of Good Corporate Governance (henceforth: GCG). As a series of moral principles distinguishing the wrong from the true, ethic plays a decisive role in business activities such as that in a corporation in which governance is conducted. ${ }^{1}$

Business is a series of events which involve business actors. They tend to break their mutual interests, do everything to get profit as much as possible, and 
defeat each other. The strong business actor will become dominant, and the weak will be dominated. ${ }^{2}$ All agree that the implementation of GCG in a corporation is a must. However, the implementation of its principles is a choice, since GCG is much more about ethic than mandatory. So, what about ethical principles run effectively in corporations in Indonesia, while they depend on obscure sanctions?

The implementation of GCG needs consistent and sustainable law enforcement. To define corporate governance, the writers quote the definition made by Cadbury Committee, an institute established by Bank of England which served to formulate the corporate governance code. This committee defines corporate governance as a directing and controlling system of corporation aimed at the achievement of the balance between power authority of a corporation to guarantee its existence and its responsibility to stakeholders. This is related to the authority rules of the owner, managing directors, stakeholders, and so forth. ${ }^{3}$

Mas Achmad Daniri defines GCG as "corporate governance which guarantees the sustainability of the system and process of making decisions of corporation organs based on principles of justice, transparency, responsibility, and accountability. In the process of making decisions, corporation organs have to do with stakeholders of corporations such as creditors, suppliers, communities, consumers, government, mass media and non-government organizations."4

In Indonesian, governance is often translated into "pengaturan" (ruling, arranging). While in the context of GCG, governance can be translated into "tata pamong" or "penadbiran". This latter seems unfamiliar for commoners since it is Malay. Among businessmen, GCG is generally translated into "tata kelola perusahaan", although this is confused with "management". Seen from this, a further study on the true term for GCG in Indonesian is need. Furthermore, GCG is defined as a relation, system and process by corporation organs (BOD, BOC, RUPS) to provide additional values to stakeholders continuously and in the long term, by always taking other stakeholders into consideration. And this should be conducted according to the rules and norms.

Thus, Good Corporate Governance is: 
1. A structure that regulates a harmonious relation between commissary council, director, and stakeholders.

2. A system of checking and authority balance of corporation control which prevents a corporation from two possibilities: mismanagement and misuse of corporation asset.

3. A transparent process of determining the goal, achievement and synergic measurement of a corporation.

Stijn Claessens states that corporate governance can be meant into two categories. Firstly, it is a series of behavioural patterns of a corporation measured from its synergy, growth, and structure of financial treatment towards stakeholders. Secondly, it is a normative framework, including legal rules, legal systems, financial market, and others that influence corporation behaviour. 5 Related to principles of GCG, the writers of this book quote the view of Saleem Seikh and William Rees that the process of corporate governance covers four principles of activities. First is direction which focuses on the formulation of strategic orientation to the future of corporation in the long term. A second principle is the executive action which is implemented in decision making. Third is monitoring which includes monitoring performance by management. Fourth and the last is accountability which focuses on the responsibility of decision makers. ${ }^{6}$ According to Robert I. Tricker, these four principles are the major tasks of corporate governance. 7

In the Decree of the State Minister of Investment and State Corporation Enterprises, SK. No. Decree 23/M-PM. PBUMN/2000, it is stated that there are three principles that should be implemented in the governance of economic institutions in BUMN as the implementation of GCG: transparency, self-reliance, and accountability. ${ }^{8}$ National Policy Committee of GCG has set out code for good corporate governance in March 2000 including transparency, accountability, fairness and self-reliance. ${ }^{9}$

The writers' opinion in this book is similar to that of Emil Salim. According to Salim, good governance includes a number of principles. The first principle is 
fairness applied both to all stakeholders and to transaction with partners. Second is financial and operational transparency towards stakeholders and government. The third principle concerns accountability within the relation between the responsibility of commissary council and directors of a corporation. The last principle is the responsibility of the corporation for the enactment of legal rules. 10

Sita Supomo further explains the principles of GCG. He said that the responsibility includes internal and external responsibilities. The internal responsibility is oriented to the internal members of a corporation, while the external one is concerned with the responsibility to wider communities. To this principle, Sita Supomo adds three other principles including fairness, transparency, and accountability. According to her, there is a basic difference between these principles. First three principles much more emphasize the interest of stakeholders so that they represent a shareholders-driven concept. This should be implemented, for instance, in the fair treatment toward the holders of minor stakes (fairness), accurate and on-time presentation of financial report (transparency), and function and authority of RUPS, commissaries, and directors (accountability). ${ }^{11}$

As regards responsibility, a significant emphasis should be given to the interest of stakeholders. The corporation has to take into consideration the interest of stakeholders, create the added value of production and service for stakeholders, and maintain the continuity of that added value. Therefore, responsibility represents much more a stakeholders-driven concept. 12

In this regard, it is clear that the writers only make a repetition, restatement, and re-explanation of the previous opinions. An innovation is only made to systematize them into a book.

Seen from the institutional perspective, corporate governance is closely connected with the public decision making, since law, regulation and institution are the main sources for the normative corporate governance framework in a government. Regulations concerning market capital, limited company, banking, 
assurance, and bankruptcy will influence the policy and behaviour of the corporation. 13

The writers of this book in fact want to show the importance of law enforcement by the government so that the principles of GCG can be implemented. GCG is closely related not only to economic activities but also to law, politic, culture and other disciplines. Policy makers are responsible to maintain the balance between the rules they have made and the agreements made by market actors. Law and its enactment by regulating institutions and the court are of the decisive part of the establishment of good corporate governance. ${ }^{14}$

Economic development is the prime mover of the development. Economic development, however, should go hand in hand with other aspects of development. In this regard, economic development has a mutual relation with law. ${ }^{15}$ On this, Sunarjati Hartono says:

“... the development of basic ideas in economy plays a significant role in changing and determining the related basic systems of law, so the enforcement of relevant legal principles also will run the formulation of intended economic structures. Conversely, the enforcement of irrelevant legal principles will constrain the establishment of idealised economic structures."16

A number of surveys by international research institutions after the crisis 1997 concluded explicitly that poor corporate governance was one of the major factors stimulating economic declines in a number of countries, including Indonesia. Johnson, Boone, Breach and Friedman have evidenced that the implementation of corporate governance in poor legal systems had caused a wider economic crisis in Asia.

The poor implementation of corporate governance has become a sound reason of currency crisis and the decrease of capital market synergies, in addition to other economic reasons. 17

Various attempts have been made to formulate, elaborate and refine the rules of corporate governance in the form of regulation. Law enforcement, 
especially concerning of contract legal system, influences the implementation of corporate governance. Based on their study in various countries, Defon and Hung have found that law enforcement is far more important than the rules which have been made. No surprise that the implementation of GCG is decreasing, since the law enforcement and the functioning of the rules are ineffective. 18

A survey on Good Corporate Governance in 2002 by Credit Lyonnais SA (CLSA) in Paris has shown that the implementation of GCG in Indonesia was declining. In this regard, Indonesia was not at the top 20 in the world, but under Singapore and Malaysia. Singapore scored 7,4 and Malay 4,7, while Indonesia scored 2,9. 19

It is significant to note the statement of Theo F Toemion, chief of BKPM, that the implementation of governance in Indonesia, either in government or private sectors, is poor. In such a condition, Indonesia even receives big capital inflow. The value of approved Foreign Direct Investment (FDI) during the crisis 1997-1999 still shown an increase, from US\$10.9 milliard in 1999 to US\$14.4 milliard in 2000 (EIU, Indonesia Country Forecast 2001-2002). This value shows that bad mental credibility and rules of law at the time had not been a significant barrier for the growth of corporate sectors. However, this condition had caused crisis. 20

The implementation of GCG is also related to politic, since law and politic are related to and influence one another. This is in line with Mahfud MD's opinion that law product will be determined by power balance or political configuration. This assumption is based on the fact that every law product may be considered as the crystallization of political thoughts among politicians. ${ }^{21}$ According to Daniri, even composition of votes for general election will also influence the implementation of GCG. For instance, the election 1999 which resulted in no single majority had often forced the government to take compromise policies. All this less helped accelerate the implementation of GCG in Indonesia, different from that in other Asian countries which was more developed. 
David Vogel, Solomon Lee Professor of Business Ethics at Haas School of Business and Professor of Political Science at the University of California Berkeley, in his book Trading $U p$, discuses about environment regulation and in his Kindred Strangers he discuses about the relation between business and politic. $^{22}$

According to Emil Salim, in its practice good governance relies on the rules of law, especially related to economic and politic, determination of transparent policy, realisation of accounted policies, qualified bureaucracy and capable society.

Accountability (political and public), rules of law, transparent information of government policies and monitoring are closely related to the covenant on civil and political rights and covenant on economic, social, and cultural rights. Therefore, the core of good governance is to promote democracy, rule of law and human rights on the ground that marker and government will function effectively only if controlled by voters. ${ }^{23}$ One of guiding points of the implementation of GCG conveys the importance of the creation of good political systems and the integrated and professional state officials. 24

Then what is about the relation between stakeholders' corporation and the implementation of GCG principles? And what is about the mechanism of the principles to meet the interest of stakeholders? Before answering these questions, the writers of this book explain who stakeholders who are, according to them, individuals as well as groups influencing on corporation activities.

Theoretically, stakeholders can be divided into twofold:

1. Primary stakeholders: stakeholders, investors, employees and managers, business partners, and societies;

2. Secondary stakeholder: government, business institutions, social groups, academician and competitors. 25

The setting-up of the principles of GCG is aimed at the creation of the harmonious relation between stakeholders, staffs, creditors, government, and 
employees in terms of their rights and duties. In general, the implementation of GCG is aimed at:

1. Facilitating the access to domestic as well as foreign invests.

2. Gaining lower cost capital;

3. Making better decisions to improve the corporation's economic synergy;

4. Improving the confidence and trust of stakeholders in the company;

5. Protecting directors and commissaries from prosecution. 26

The principles of GCG (fairness, transparency, accountability and responsibility) should meet and protect the interest of both primary and secondary stakeholders. However, priority should be given to the interest of primary stakeholders. If the principles are properly applied, the rights and interests of all stakeholders are secured. In addition to getting the interests, the stakeholders will have an equal treatment and protection from the company, regardless of their being majority or minority. These interests can be met with the first principle of GCG, i.e. fairness which demands that the company give an equal place to stakeholders. 27 The second principle of GCG, transparency, will make it possible to get easy access to information of materials concerning the company. This transparent information is not absolute in the sense that there are always limitations as to information which might be publicly accessed.

To solve the possible conflict between directors as the direct agents of stakeholders in running the company, and the other stakeholders, the third principle, accountability can be applied. This principle should be based on an internal checks and balances system through fair audit. Accountability can be established through effective monitoring based on the balanced authority of stakeholders, commissaries and managers. 28

People as main consumers have the right to get good products and services with reasonable prices. In addition, they deserve to get proper protection. ${ }^{29}$ The principles of responsibility can be implemented to meet this aim. Related to the public interest, this principle will guarantee the sustainability of a company. Its sustainability depends on to the extent it runs the corporate social responsibility 
(CSR). This is because CSR and GCG are two faces of the same coin, interrelated and inseparable. CSR is a part of the responsibility of a corporation.

In the CSR, the responsibility of a corporation is not based on a single bottom line, i.e. the corporate value as represented by financial condition. Conversely, the responsibility is based on triple bottom lines. In this regard, in addition to financial condition, social and environmental conditions are instrumental. Financial condition will not adequately guarantee the corporate value to reach a sustainable growth. The sustainability will be reached only if social and environmental dimensions are seriously taken into consideration. Surrounding communities will resist if a corporation pays less attention to environment as can be seen in the case of Indorayon in North Sumatra. 30

From the above explanation, it can be said that the implementation of the principles of GCG is very much related to the interest of all the concerned. Even it can be said that the principles are the key pillars in fulfilling the interest of all stakeholders in a corporation. The interest of a corporation is therefore the compromised interest of all stakeholders. The principles of GCG become a set of guidance for fulfilling the balanced interest of stakeholders. If the balance is reached, the interest of corporation is well organised.

In part III, the writers of this book explain about the national jurisdiction concerning the principles of GCG implemented in Indonesia. This part describes the principles of GCG in Undang-Undang Perseroan Terbatas, BUMN, Banking and Capital Market. A number of examples concerning the implementation of GCG in Indonesia are provided. The writers mention PT. Astra Tbk, Bank Niaga Tbk, PT. Dankos Laboratories Tbk, Royal Ahold and Air Liquide as the examples of the successful corporations. On the other hand, such cases as those of PT. Kopitme Dot Com Tbk, PT. Jakarta International Hotels \& Development Tbk, Litter of Credit BNI 46 and the closure of PT. Bank Global Tbk are the examples of the corporations breaking the principles of GCG.

In general, the writers conclude that the implementation of GCG in Indonesia is far from the hope. Breaking the principles of GCG is not a new phenomenon. Bribery is the most common way of a corporation to win a tender. 
As a consequence, the government should often pay irrational costs for it. ${ }^{31}$ The emergence of bad trading practices is stimulated by the fact that rulers often give privileges to certain business actors as the result of collusion, corruption and nepotism. 32

England had ever witnessed the heyday of industry in 1760. Businessmen were free from any rules of law to the extent that they earned a vast amount of interest with very low waged employees. In such a condition, employers did not care about their employees. A number of intellectuals such as Sir Robert Peel and Robert Own tried to struggle for the rules of law which protected all related parts of a corporation. Their struggle resulted in "Factory Laws" as part of the government's interference with economic life after Adam Smith. ${ }^{33}$ This shows that the rules of law are very important in business activities.

The effective implementation of the principles of GCG will come into being if the ethic values are obeyed in business. This is only possible if the rules of law are realized. To protect stakeholders, law enforcement and regulation must be enacted. 34

In essence, law and regulation in Indonesia have adopted the principles of GCG explicitly or implicitly. In this regard, what is needed is the role of public institutions such as court, BAPEPAM, self-regulatory organization, Bank of Indonesia or judiciary, police, and others. These institutions play a significant role in strengthening legal protection to stakeholders and the realization of GCG principles.

Law enforcement is the main pillar of sustainability of corporation and business. Failure to establish law enforcement will fail to protect individual rights and this will influence the attitude of investors and stakeholders. Firm, consistent and sustained law enforcement is significant in the implementation of GCG in Indonesia.

\footnotetext{
*A lecturer of law at the University of Pekalongan and can be reached at
} moostofa@yahoo.com 
1 According to Rafiq Issa Beekun, ethic can be defined as a series of moral principles differentiate the good and the bad. It is a normative science it plays a decisive role in determining what must and must not be done. Business ethic sometimes refers to management or organisational ethics, simply confining the term of reference to a corporate conception. Rafiq Issa Bekun (1997), Islamic Business Ethics, Virginia: The International Institute of Islamic Thought.

2 Muhammad (2002), Etika Bisnis Islami (Yogyakarta: Akademi Manajemen Perusahaan YKPN), p. 41.

3 Indra Surya \& Ivan Yustiavandana (2006), Penerapan Good Corporate Governance (Mengesampingkan Hak-hak Istimewa Demi Kelangsungan Usaha), Jakarta: Kencana, p. 25.

${ }^{4}$ Mas Achmad Daniri (2004), Membudayakan 'Good Corporate Governance' http://www.kompas.com/kompas\%2Dcetak/0404/15/ekonomi/970822.htm, accessed on Thursday, 15 April 2004.

5 Indra Surya \& Ivan Yustiavandana (2006), Op. Cit., p. 26

6 Ibid., p. 28; Lihat juga Saleem Seikh dan William Rees (tt), Corporate Governance \& Corporate Control", London: Cavendish Publishing Limited, p. 5.

7 Tricker, Robert I. (1984), Corporate Governance - Practices, Procedures, and Power in British Companies and Their Board of Directors, UK, Gower.

8 Hassel Nogi S. Tangkilisan (2003), Good Corporate Governance, Yogyakarta: Balairung: p. 11.

${ }^{9}$ Ibid. p. 11.

10 Emil Salim (1999), "Good Governance dan Masyarakat Warga" in E-Journal Transparans, 15 December 1999. http://www.transparansi.or.id. (accessed 25/04/2000)

11 Sita Supomo (2004), "Corporate Social Responsibility (CSR)" in Prinsip GCG, http://www.republika.co.id/suplemen/cetak_detail.asp?mid=3\&id=176267\&kat_id=105\&kat_id1= 149 \&kat_id2=313 (Rabu, 20 Oktober 2004). (accessed 5/08/2005)

12 Ibid.

13 Indra Surya \& Ivan Yustiavandana (2006), Op. Cit., pp. 9-10.

14 Ibid. p. 10.

15 Johannes Ibrahim \& Lindawaty Sewu (2004) Hukum Bisnis dalam Persepsi Manusia Modern, Bandung: Refika Aditama, p. 23.

16 Sunarjati Hartono (1982), Hukum Ekonomi Pembangunan Indonesia, Bandung: Bina Cipta. pp. 6-7.

17 Indra Surya \& Ivan Yustiavandana (2006), Op. Cit., p. 10.

18 Ibid., p. 27.

19 Mas Ahmad Daniri (2004), Op. Cit.

20 Ubaidillah Nugraha (2002), "Bad Corporate Governance, Kasus Amerika Serikat dan Indonesia" http://www.freelists.org/cgi-bin/list?list_id=untirtanet. (diakses 23/04/2003).

21 Moh Mahfud MD. (1999), Pergulatan Politik dan Hukum di Indonesia, Yogyakarta: Gama Media, p. 4.

22 Gatot Arya Putra (2006), Beretorika untuk Kemiskinan, http://www.kompas.com/kompas-cetak/0609/01/teropong/2921526.htm. Friday, 1 September 2006.

23 Emil Salim (1999), Op. Cit.

24 EDITO COMEFROMKomisi Pemberantasan Korupsi Republik Indonesia: http://www.kpk.go.id/modules/edito/content.php?id=27 (accessed 14/04/2005).

25 Good Corporate Governance (http//www.sdp.-consulting.com/history.htm) accessed June 2007.

26 Indra Surya \& Ivan Yustiavandana (2006), Op. Cit. p. 68. 
27 Ibid. pp. 71-73.

28 Ibid., pp. 76-77.

29 In Indonesia, consumer protection is a something new, especially in law regulations. Law on consumer protection was set up by the government on 20 April 1999. Gunawan Widjaja \& Ahmad Yani (2003), Hukum tentang Perlindungan Konsumen (Jakarta: PT. Gramedia) pp.1-2

30 Sita Supomo (2004), Op. Cit.

31 Ubaidillah Nugraha (2002), Op. Cit.

32 Rachmadi Usman (2004), Hukum Persaingan Usaha di Indonesia, Jakarta: PT. Gramedia. p.1.

33 Edi Sopandi (2003), Beberapa Hal dan Catatan Berupa Tanya Jawab Hukum Bisnis, Bandung: Refika Aditama. p. 3.

34 Indra Surya \& Ivan Yustiavandana (2006), Op. Cit. p. 125. 